\title{
An IR Study of Benzoyl Chloride Adsorbed on KA, NaA, and CaA Zeolites
}

\author{
B. Bardakçı and Semiha Bahçeli \\ Department of Physics, Faculty of Arts and Sciences, Süleyman Demirel University, 32260 Isparta, \\ Turkey \\ Reprint requests to Dr. S. B.; E-mail: bahceli@fef.sdu.edu.tr
}

Z. Naturforsch. 60a, 637 - 640 (2005); received November 24, 2004

\begin{abstract}
Infrared spectroscopy has been used to investigate the adsorption of liquid benzoyl chloride on A-type zeolites. The data show that at room temperature the Fermi resonance phenomenon occurs in the adsorption on $\mathrm{KA}, \mathrm{NaA}$ and $\mathrm{CaA}$ zeolites which are little acidic aluminosilicates.
\end{abstract}

Key words: IR; Benzoyl Chloride; Fermi Resonance; A-type Zeolites.

\section{Introduction}

Benzoyl chloride is a highly reactive acyl halide and is therefore used as benzoylation agent. The benzoylation of various acidic zeolites has given information about their structural, chemical and catalytic characteristics [1-3]. Recently, the vibration of benzoyl chloride in the liquid and vapour phase, adsorbed on the NaY-FAU zeolite, was studied [4]. The infrared frequencies of liquid benzoyl chloride have been reported by Rasmussen and Brattain [5]. They have observed two bands at 1773 and $1736 \mathrm{~cm}^{-1}$ in the double bond region, which differ from those of other carboxylic acids. Much more detailed vibrational studies of benzoyl chloride revealed that the mentioned bands were the $\mathrm{C}=\mathrm{O}$ streching vibration at $1774 \mathrm{~cm}^{-1}$ and the overtone vibration at $1733 \mathrm{~cm}^{-1}$ of $v(\mathrm{C}-\mathrm{Cl})$ $\left(2.872 \mathrm{~cm}^{-1}\right)$, which was assigned to the Fermi resonance phenomenon $[6,7]$.

In the following we present an IR study of liquid benzoyl chloride adsorbed on A-type zeolites.

\section{Experimental}

The synthetic zeolites KA (type 3A), NaA (type 4A), and $\mathrm{CaA}$ (type 5A) were obtained from the Aldrich Chemical Company. The unit cell contains

$$
\mathrm{M}_{12}\left[\left(\mathrm{AlO}_{2}\right)_{12}\left(\mathrm{SiO}_{2}\right)_{12}\right] \cdot 27 \mathrm{H}_{2} \mathrm{O}
$$

where $\mathrm{M}=\mathrm{K}, \mathrm{Na}$ and $\mathrm{Ca}$. Benzoyl chloride $\left(\mathrm{C}_{6} \mathrm{H}_{5} \mathrm{COCl}\right)$ (Merck, 99\%) was used without purification. As for the preparation of the samples, the mentioned zeolites were activated at $623 \mathrm{~K}$ for $4 \mathrm{~h}$, and then
$1 \mathrm{~g}$ of each zeolite was placed into $40 \mathrm{ml}$ of liquid benzoyl chloride. After stirring and storing for $24 \mathrm{~h}$, the mixtures were filtered and washed twice with diethyl ether and then filtered again and dried at room temperature.

The samples were compressed into self-supporting pellets and introduced into an IR cell equipped with $\mathrm{KBr}$ windows. The IR measurments at room temperature were performed on a Perkin-Elmer BX FT-IR (Fourier Transformed Infrared) spectrometer at a resolution of $4 \mathrm{~cm}^{-1}$ in the transmission mode.

\section{Results and Discussion}

The IR spectra of benzoyl chloride adsorbed on KA, $\mathrm{NaA}$, and CaA zeolites are given in Figs. 1, 2 and 3, respectively. The data are summarized in Table 1.

For the assignments of the infrared vibrational frequencies of bulk benzoyl chloride we refer to $[4,5,8]$. As we mentioned in the introduction, the characteristic vibrational bands of bulk benzoyl chloride are $v(\mathrm{C}=\mathrm{O})$ and $v(\mathrm{C}-\mathrm{Cl})$ stretching bands at $1774 \mathrm{~cm}^{-1}$ and the band called Fermi resonance phenomenon at $1733 \mathrm{~cm}^{-1}$, which is twice the $\mathrm{C}-\mathrm{Cl}$ stretching vibration band at $872 \mathrm{~cm}^{-1}$ [4]. The former bands of benzoyl chloride adsorbed on A-type zeolites are observed as medium bands at $1787 \mathrm{~cm}^{-1}$ in the higher frequency region. The Fermi resonance bands of benzoyl chloride adsorbed on $\mathrm{KA}, \mathrm{CaA}$, and $\mathrm{NaA}$ zeolites arise at $1725 \mathrm{~cm}^{-1}, 1727 \mathrm{~cm}^{-1}$ and $1725 \mathrm{~cm}^{-1}$, respectively, and are shifted to lower frequencies. On the other hand, the $\mathrm{C}-\mathrm{Cl}$ streching vibration band at $872 \mathrm{~cm}^{-1}$ for bulk benzoyl chloride is observed as a broad weak band at $945 \mathrm{~cm}^{-1}$ for benzoyl chloride adsorbed on KA zeo- 




Fig. 1. Infrared spectrum of benzoyl chloride adsorbed on KA zeolite.

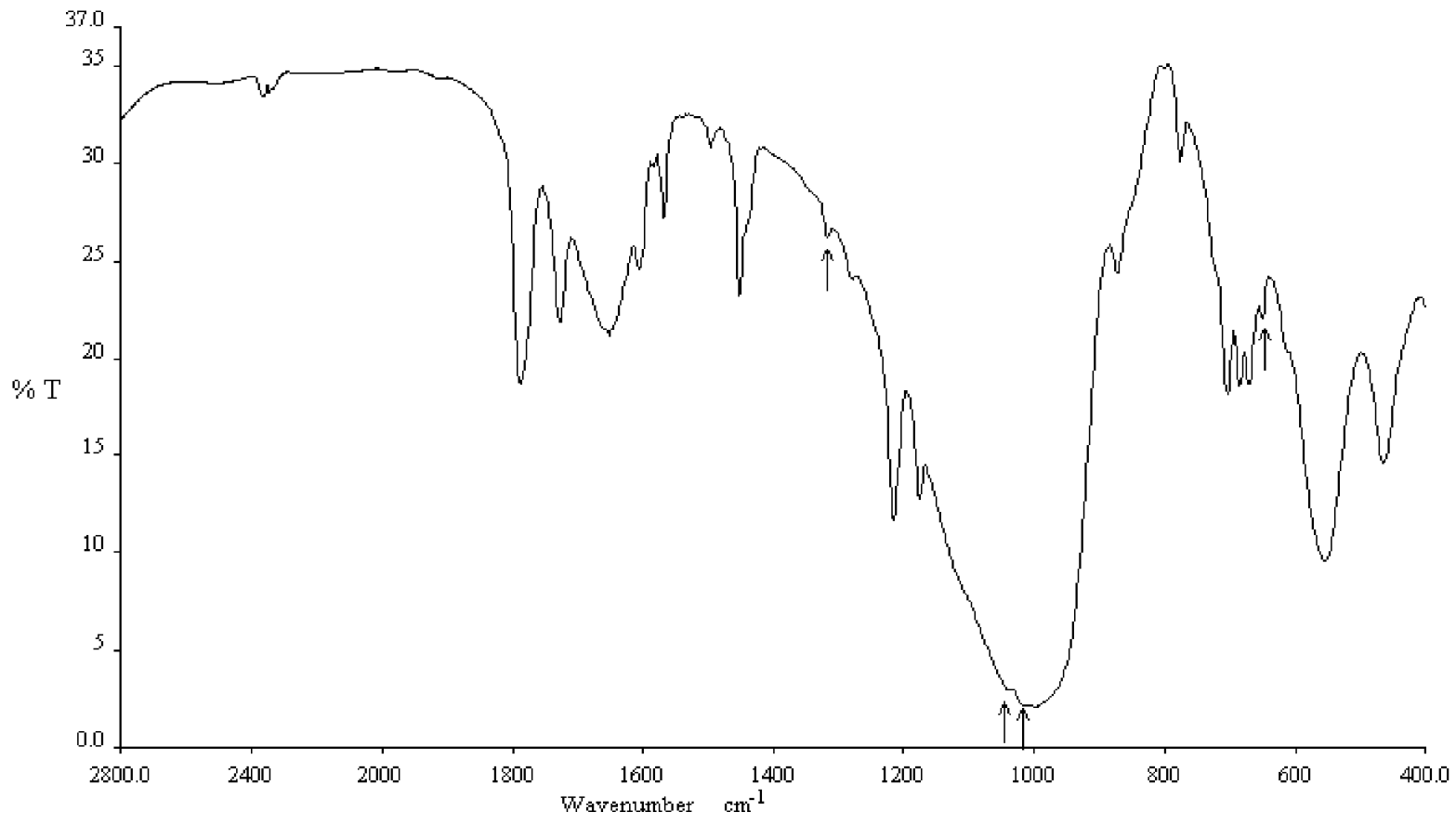

Fig. 2. Infrared spectrum of benzoyl chloride adsorbed on CaA zeolite. 


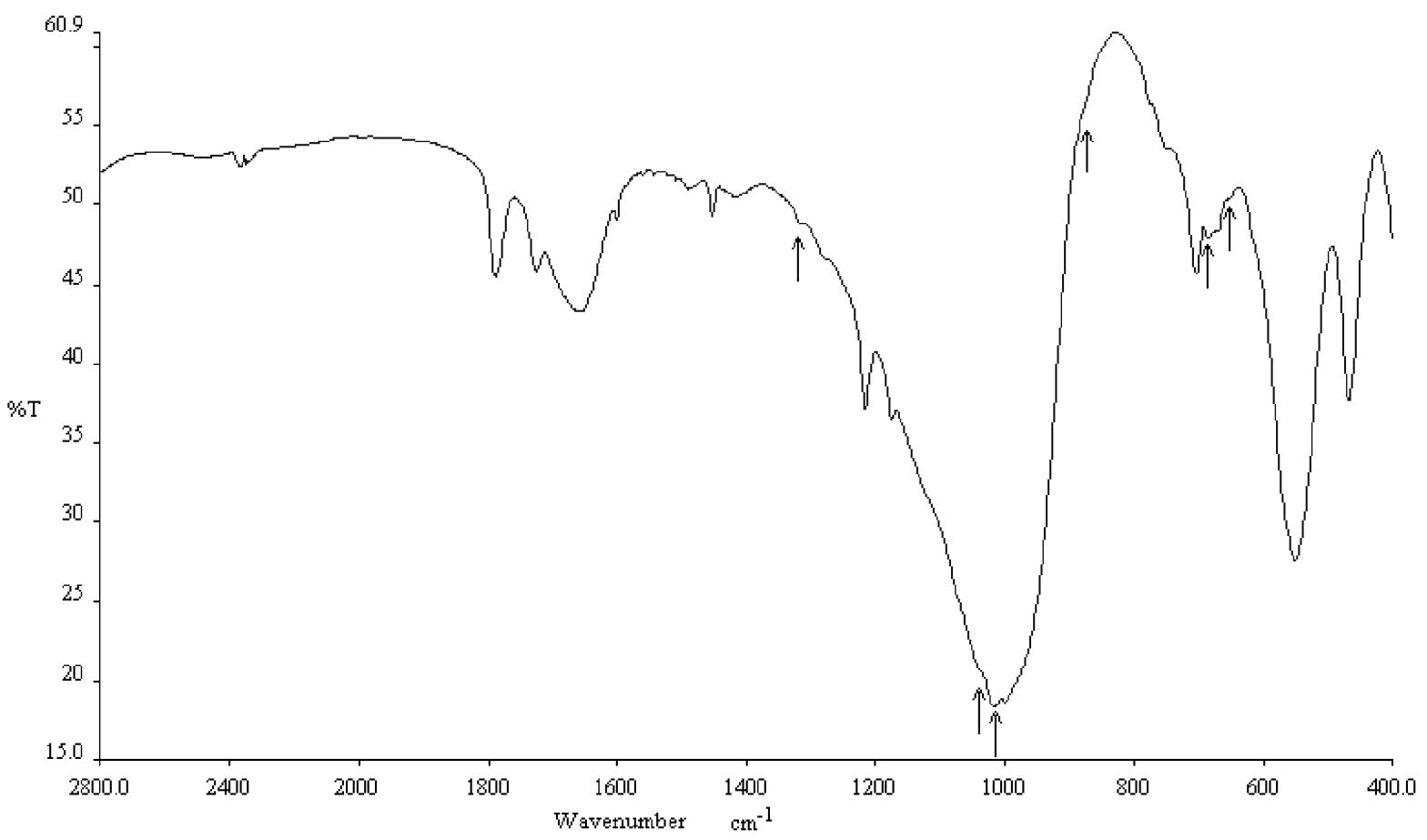

Fig. 3. Infrared spectrum of benzoyl chloride adsorbed on NaA zeolite.

Table 1. The IR frequencies $\left(\mathrm{cm}^{-1}\right)$ of liquid benzoyl chloride and adsorbed bezoyl chloride on $\mathrm{KA}, \mathrm{CaA}$ and $\mathrm{NaA}$ zeolites.

\begin{tabular}{rlccc}
\hline $\begin{array}{l}\text { Benzoyl } \\
\text { chloride }\end{array}$ & Assignment & \multicolumn{3}{c}{ Benzoyl chloride adsorbed on } \\
\hline $1774 \mathrm{~s}$ & $v(\mathrm{C}=\mathrm{O})$ & $1787 \mathrm{~m}$ & $1787 \mathrm{~m}$ & $1787 \mathrm{~m}$ \\
$1733 \mathrm{~s}$ & $v(\mathrm{C}-\mathrm{Cl})$ & $1725 \mathrm{~m}$ & $1727 \mathrm{~m}$ & $1725 \mathrm{~m}$ \\
$1595 \mathrm{~s}$ & $v(\mathrm{Ph}-\mathrm{C})$ & $1599 \mathrm{w}$ & $1605 \mathrm{w}$ & $1599 \mathrm{w}$ \\
$1582 \mathrm{~s}$ & $v(\mathrm{Ph}-\mathrm{C})$ & & $1567 \mathrm{w}$ & \\
$1450 \mathrm{~s}$ & $v(\mathrm{Ph}-\mathrm{C})$ & $1451 \mathrm{~m}$ & $1451 \mathrm{~m}$ & $1451 \mathrm{~m}$ \\
$1316 \mathrm{~m}$ & $\mathrm{C}-\mathrm{H}$ bend & $1317 \mathrm{w}$ & $1316 \mathrm{w}$ & $1316 \mathrm{w}$ \\
$1205 \mathrm{~s}$ & $\mathrm{C}-\mathrm{H}$ scissor & $1214 \mathrm{~m}$ & $1214 \mathrm{~m}$ & $1214 \mathrm{~m}$ \\
$1175 \mathrm{~s}$ & $\mathrm{C}-\mathrm{C}$ out-of-plane-scissor & $1173 \mathrm{w}$ & $1174 \mathrm{w}$ & $1173 \mathrm{w}$ \\
$1038 \mathrm{~m}$ & $\mathrm{C}-\mathrm{C}$ out-of-plane-scissor & $1039 \mathrm{w}$ & $1041 \mathrm{w}$ & $1039 \mathrm{sh}$ \\
$1016 \mathrm{~s}$ & $\mathrm{C}-\mathrm{C}$ out-of-plane-scissor & $1017 \mathrm{w}$ & $1017 \mathrm{w}$ & $1015 \mathrm{w}$ \\
$872 \mathrm{~s}$ & $v(\mathrm{C}-\mathrm{Cl})$ & $945 \mathrm{bsh}$ & $873 \mathrm{w}$ & $872 \mathrm{sh}$ \\
$774 \mathrm{~s}$ & $v(\mathrm{C}-\mathrm{Cl})$ & $777 \mathrm{w}$ & $776 \mathrm{w}$ & $778 \mathrm{w}$ \\
$684 \mathrm{~m}$ & $v(\mathrm{C}-\mathrm{Cl})$ & $685 \mathrm{w}$ & $685 \mathrm{w}$ & $684 \mathrm{w}$ \\
$670 \mathrm{~s}$ & $v(\mathrm{C}-\mathrm{Cl})$ & $668 \mathrm{w}$ & $670 \mathrm{w}$ & $669 \mathrm{w}$ \\
$649 \mathrm{~s}$ & $v(\mathrm{C}-\mathrm{Cl})$ & & $650 \mathrm{w}$ & $650 \mathrm{w}$ \\
\hline
\end{tabular}

s, strong; m, medium; w, weak; bsh, broad shoulder; sh, shoulder; $v$, stretching.

lite (shown with an arrow in Fig. 1) and at $872 \mathrm{~cm}^{-1}$ (shoulder band) and $873 \mathrm{~cm}^{-1}$ (weak band) for adsorbed benzoyl chloride on $\mathrm{CaA}$ and $\mathrm{NaA}$ zeolites (denoted with arrows in Figs. 2 and 3), respectively.

As seen in Table 1, the $\mathrm{C}-\mathrm{H}$ bending vibration mode at $1316 \mathrm{~cm}^{-1}$, the $\mathrm{C}-\mathrm{C}$ out-of-plane-scissor mode at
$1038 \mathrm{~cm}^{-1}$ and $1016 \mathrm{~cm}^{-1}$, and the $\mathrm{C}-\mathrm{Cl}$ stretching vibration band at $684 \mathrm{~cm}^{-1}$ and $649 \mathrm{~cm}^{-1}$ for bulk benzoyl chloride are observed in the IR spectra of adsorbed benzoyl chloride on $3 \mathrm{~A}, 4 \mathrm{~A}$, and $5 \mathrm{~A}$ zeolites as weak bands at $1317 \mathrm{~cm}^{-1}$ and $1316 \mathrm{~cm}^{-1}, 1039 \mathrm{~cm}^{-1}$ and $1041 \mathrm{~cm}^{-1}$ and as the shoulder band at $1039 \mathrm{~cm}^{-1}$ and as the weak bands at $1015 \mathrm{~cm}^{-1}$ and $685 \mathrm{~cm}^{-1}$, $684 \mathrm{~cm}^{-1}$ and $650 \mathrm{~cm}^{-1}$ which are all denoted with arrows on Figs. 1, 2 and 3, respectively.

In fact these frequency shifts to lower and higher regions show the existence of adsorption of liquid benzoyl chloride on the zeolites. The reasons of adsorption on the zeolites can be explained by considering the hydroxyl groups, structural $\mathrm{OH}$ groups and nonacid silanol ( $\mathrm{SiOH})$ hydroxyl groups, in zeolites [9].

As a conclusion we can state that the crucial point is that the Fermi resonance phenomenon was observed in the liquid phase spectra of benzoyl chloride adsorbed on A-type zeolites as the less acidic zeolite than NaY-FAU and it is obviously confirmed that there is no influence of the acidity of the zeolites as the adsorbents [10].

\section{Acknowledgements}

This work was supported by TÜBİTAK (Turkish Scientific and Technical Research Council) within 
the project No TBAG-AY/301 (103T003) and Süleyman Demirel University, The Unit of the Management

[1] B. Jacob, S. Sunugan, and A.P. Singh, J. Mol. Catal. 139, 43 (1999).

[2] D. Battacharya, S. Sharma, and A.P. Singh, Appl. Catal. A: General 139, 53 (1997).

[3] P. Laidlaw, D. Bethell, S. M. Brown, and G. J. Hutchings, J. Mol. Catal. 165, 243 (2001).

[4] I. Hannus, T. Kollar, Z. Konya, and I. Kiricsi, Vib. Spectrosc. 22, 29 (2000).

[5] R. S. Rasmussen and R. R. Brattain, J. Am. Chem. Soc. Mineral Soc. 71, 1073 (1949).

[6] M. St. C. Flett, Trans. Faraday Soc. 44, 767 (1948). of Scientifical Research Projects within the project No. 621.

[7] C. N. R. Rao and R. Venkataraghavan, Spectrochim. Acta 18, 273 (1962).

[8] G. Varsanyi and S. Szöke, Vibrational Spectra of Benzene Derivatives, Academic Press, New York 1969.

[9] J.W. Ward, In: Infrared Spectroscopic Studies in Molecular Sieves Zeolites-I (Ed. R. F. Gould), Advances in Chemistry Series 101, Am. Chem. Soc. Washington 1971, Chapter 29, pp. 380-405.

[10] Z. Konya, I. Hannus, and I. Kirisci, Appl. Catal. B: Environmental 8, 391 (1996). 